\title{
CHITOSAN SUPPORTS CONTAINING IMPATIENS NOLI-TANGERE AND SYMPHYTUM OFFICINALE HYDROALCOHOLIC EXTRACTS IN BURNS TREATMENT: ANTIMICROBIAL AND HEALING EFFECTS
}

\author{
ANCA ZANFIRESCU ${ }^{1}$, CRISTINA DANIELA MARINECI ${ }^{1 *}$, GABRIELA PĂUN ${ }^{2}$, OANA \\ UNGUREANU $^{2}$, ELENA NEAGU ${ }^{2}$, CORNEL CHIRIȚA ${ }^{1}{ }^{1}$, BRUNO ȘTEFAN VELESCU ${ }^{1}$, \\ OCTAVIAN TUDOREL OLARU ${ }^{1}$, SIMONA NEGREȘ ${ }^{1}$
}

\author{
${ }^{I}$ Faculty of Pharmacy, "Carol Davila" University of Medicine and Pharmacy, Bucharest, Romania
}

${ }^{2}$ National Institute for Research-Development of Biological Sciences, Bucharest, Romania

*corresponding author: danamarineci@gmail.com

Manuscript received: December 2020

\begin{abstract}
Burn injuries have a major impact on population health, an optimal burn wound dressing with both healing and antibacterial effect being needed. Our purpose was to assess the healing efficacy of chitosan supports containing different quantities of a hydroalcoholic extract obtained from Impatiens noli-tangere and Symphytum officinale, in a rat burn wound model. The antibacterial effect of the extract was also assessed. The efficacy of topical daily administration of the supports and of silver sulphadiazine was evaluated by measuring the thermal lesion area. In addition, tissular hydroxyproline content and IL-6, TNF-alpha plasmatic levels were measured. The chitosan support with the highest content of plant extract showed the most pronounced healing effect. The mixed extract was shown to possess a moderate antibacterial effect, the most sensitive microorganism being $S$. aureus.
\end{abstract}

\section{Rezumat}

Arsurile au un impact major asupra sănătăţii populației, pansamentul optim al arsurilor necesitând, atât efect de vindecare cât și antibacterian. Scopul studiului a fost de a evalua eficacitatea suporturilor de chitosan conținând cantități diferite de extract hidroalcoolic obținut din Impatiens noli-tangere și Symphytum officinale, într-un model de leziuni termice la şobolani. De asemenea, a fost evaluat efectul antibacterian al extractului. Eficacitatea administrării locale zilnice a suporturilor și a sulfadiazinei de argint a fost evaluată prin măsurarea ariei leziunii. În plus, au fost determinate conținutul de hidroxiprolină tisular și nivelele plasmatice IL-6, TNF-alfa. Suportul cu cel mai mare conținut de extract a prezentat cel mai mare efect de vindecare. Extractul mixt a demonstrat efect antibacterian moderat, microorganismul cel mai sensibil fiind S. aureus.

Keywords: chitosan, healing effect, burn wound model, Impatiens noli-tangere, Symphytum officinale

\section{Introduction}

Burns are pathologies associated with high morbidity and mortality. Worldwide, more than 6 million people suffer from severe burns, with a rate of death exceeding 300,000 persons per year [1]. The topical preparations available for their treatment contain mainly antibacterial substances, such as silver sulphadiazine, rather than substances promoting healing [2]. Several medicinal plants improve the healing process of burn wound, by promoting various phases of the wound healing process $[3,4]$.

The rat burn model was found to possess translational accuracy in wound healing studies [5]. The thermal lesion results in an inflammatory response, with macrophages being attracted to the wound site. They impede microbial wound infection and initiate wound closure. Secreted cytokines, such as tumoural necrosis factor alpha (TNF- $\alpha$ ) and interleukin-6 (IL-6), activate fibroblasts to produce type III collagen and fibronectin and also to secrete further cytokines which in turn attract keratinocyte cells to the injury site [6]. Keratinocytes are essential in the re-epithelialisation process, thus restoring the barrier function of the epithelium [7].

Symphytum officinale L., comfrey, Boraginaceae family, has been used in traditional medicine for its anti-inflammatory, analgesic and anti-oedematous effects, attributed to polysaccharides and polyphenolic compounds in its composition $[8,9]$. The content in allantoin, another main constituent of $S$. officinale, is positively correlated with cell division intensification, the growth of connective tissue, bone, cartilage and with wound healing enhancement $[8,9]$. Impatiens noli-tangere, touch-me-not, Balsaminaceae family, is being used traditionally for its antioxidant [10-12], anti-inflammatory $[11,12]$ and anti-microbial effect [12], having a high content of organic acids, anthraquinones, flavonoids and phenolic acids.

Hydroalcoholic extracts of these two Romanian indigenous plants were embedded in chitosan dressings, 
and their healing effects were assessed using a model of rat thermal lesion. Chitosan is a biopolymer with high biocompatibility and widely used as a topical dressing in wound management as it possess intrinsic antimicrobial properties, and ensures an optimal delivery of extrinsic antimicrobial and healing agents to wounds and burns $[13,14]$.

\section{Materials and Methods}

\section{Plant material}

Extraction procedure - ultrasound-assisted extraction Ground plant material was extracted with ethanol/ water $(50 \% \mathrm{v} / \mathrm{v}$ for I. noli tangere and $70 \% \mathrm{v} / \mathrm{v}$ for S. officinale, $100 \mathrm{~g}$ ground material per litre of solvent) in an ultrasonic apparatus (Elma Transsonic 460/H, frequency $35 \mathrm{kHz}$ ) for $1 \mathrm{~h}$. The extract was filtered under vacuum (No.1 Whatman filter paper), processed by microfiltration (MF) (Millipore filters with $45 \mu \mathrm{m}$ ), followed by ultrafiltration (UF) (Millipore membrane with cut-off $1000 \mathrm{Da}$ ) using a KMS Laboratory Cell CF-1.

Preparation support with bioactive compounds

Chitosan supports were prepared by evaporation method. 2.1, 4.2 respectively $6.3 \mathrm{~mL}$ of each extract were entrapped in the polymeric solution by dispersion, obtaining supports with $6 \mathrm{~cm}$ diameter.

Estimation of total polyphenols content

The phenolic total content was determined by the Folin-Ciocâlteu method, as previously described [15]. Total polyphenols content was expressed as gallic acid equivalents (GAE) in $\mathrm{mg} / \mathrm{L}$ of extract.

\section{Estimation of total flavonoid content}

The total flavonoid content was assessed using the adapted version of aluminium chloride colorimetric method [16]. The results were expressed as mg rutin equivalents (RE)/L of extract.

HPLC-MS analyses of phenolic compounds

The polyphenol content was determined using a previously described HPLC method [3], using a HPLC system, equipped with a C18 Nucleosil 3.5, $4.6 \mathrm{~mm} \mathrm{x}$ $50 \mathrm{~mm}$, Zorbax column, and coupled to a MS detector (Shimadzu LCMS-2010 EV, Shimadzu Europe). A mix of formic acid in water $(\mathrm{pH}=3.0) /$ formic acid in acetonitrile $(\mathrm{pH}=3.0)$ was employed as mobile phase. The polyphenolic compounds separation was performed using binary gradient elution. Gallic acid, chlorogenic acid, ellagic acid, caffeic acid, rutin, rosmarinic acid, luteolin, quercetin, quercetin 3- $\beta$ D-glucoside, apigenin, umbelliferone and kaempferol were used as reference standard.

Antibacterial effect of the plant extract

The hydroalcoholic plant extract was tested in vitro against 5 bacterial species and strains: Bacillus subtilis ATCC 6623, Proteus mirabilis ATCC 29245, S. aureus ATCC 25923, S. epidermidis ATCC 12228 and Escherichia coli ATCC 8739, using the disk diffusion method [17]. Sterilized Petri dishes $(9 \mathrm{~cm}$ diameter) were inoculated with $0.01 \mathrm{~mL}$ of bacterial inoculums $\left(10^{5}-10^{6}\right.$ bacteria per $\left.\mathrm{mL}\right)$, in MullerHinton agar. Sterile filter paper discs (Whatman, 6 $\mathrm{mm}$ in diameter) loaded with $6.3 \mathrm{~mL}$ mixed plant extract, were placed on the top of Mueller-Hilton agar plates. Gentamycin, ciprofloxacin and ampicillin were used as positive control. Ethanol (50\%) was used as negative control. The Petri dishes were placed at $4^{\circ} \mathrm{C}$ for $1-2 \mathrm{~h}$ and then incubated at $35 \pm 0.1^{\circ} \mathrm{C}$ for $18-24 \mathrm{~h}$. At the end of the period, the inhibition zones formed on the media were measured with a transparent ruler in millimetres.

Animals

Wistar adult male rats $(\mathrm{n}=35 ; 197 \pm 48 \mathrm{~g})$, purchased from "Carol Davila" University Biobase, Bucharest, were left for five days to accommodate, before starting experimental procedures. They were housed in a ventilated cage system, with a bedding of wood sawdust, under controlled light/dark cycle conditions (12 h light/12 h dark; lights on at 6:00 $\mathrm{AM}$ ), with free access to water and food pellets. The temperature ranged between 20 and $22^{\circ} \mathrm{C}$ and the relative humidity was maintained at $35-45 \%$. All procedures were carried out according to EU Directive 2010/63/UE and with the approval of the Institutional Animal Care and Use Committee.

Burn wound model

Rats were anesthetized with thiopental and dorsum was shaved. The shaved area was disinfected with $3 \mathrm{x}$ $3 \mathrm{~cm}$ sterile gauze soaked in alcohol. A $100 \mathrm{~g}$ cylindrical stainless-steel rod (1 cm diameter) was heated to $100^{\circ} \mathrm{C}$ in boiling water. Temperature was monitored using a thermocouple. Burn infliction was limited to the loin. The rod rested on its own weight for 10 seconds at two different sites on each rat. The size of the wounds was measured with a micrometre. Animals received analgesia during the postoperative period.

Study design

After burn infliction, the following topical treatments were applied daily: group 1 - no treatment (control group); group $2-1 \%$ silver sulphadiazine $1 \mathrm{~mL}$ per application; group 3 - chitosan support impregnated with $2.1 \mathrm{~mL}$ of mixed extract, prepared from equal quantities of each individual plant extract (S1); group 4 - chitosan support impregnated with $4.2 \mathrm{~mL}$ of mixed extract, prepared from equal quantities of each individual plant extract (S2); group 5 - support impregnated with $6.3 \mathrm{~mL}$ mixed extract, prepared from equal quantities of each individual plant extract (S3). The wounds were covered with a sterile gauze with adhesive margins and absorbent body, $7.2 \times 5 \mathrm{~cm}$ (Cosmopor, Hartmann). The general appearance and degree of wound healing of the burn wound (the lesion area) were assessed on days 1 (after 10 hours after burn infliction), 2 (after acute administration), 4 and 7 (after subacute treatment). The area of the 
lesion was calculated using the following formula: $A=\pi R_{m}{ }^{2},\left(\mathrm{R}_{\mathrm{m}}=\right.$ average radius $)$.

\section{Assessment of hydroxyproline content}

On day 8, the animals of each group were euthanized by decapitation. The tissue of the lesion was excised, weighed, dried at $600^{\circ} \mathrm{C}$ for 12 hours and the weight after drying was determined. After samples processing, the absorbance was measured at $500 \mathrm{~nm}$ and the hydroxyproline content was calculated using a standard curve of pure L-hydroxyproline [18].

\section{Assessment of cytokines concentration}

Blood was taken from the tail at day eight and centrifuged. It was determined the concentration of tumour necrosis factor alpha (TNF- $\alpha$ ) and interleukin 6 (IL-6) using an ELISA kit according to the manufacturer's instructions (Enzo Life Sciences, USA). The limits of detection for TNF- $\alpha$ and IL-6 were 5 , respectively $20 \mathrm{pg} / \mathrm{mL}$.
Statistical analysis

Statistical analysis was performed using GraphPad Prism version 5.00 for Windows (GraphPad Software, San Diego California USA). D'Agostino \& Pearson test was used for establishing the distribution of the response. Data are reported as means \pm standard error of the mean (SEM). Parametrical Student's tTest was employed. A confidence interval (CI) of $95 \%$ was employed and $p$ values of 0.05 or less were considered to be significant.

\section{Results and Discussion}

\section{Extracts characterization}

The total polyphenols and total flavonoids content measured in the extracts are presented in Table I.

The HPLC-MS analysis was used to identify the individual polyphenols present in the examined extracts. The results are displayed in Table II.

Table I

The total polyphenols and total flavonoid content of assessed extracts

\begin{tabular}{|c|c|c|}
\hline Extract & Total polyphenols content, mg GAE/L & Total flavonoids content, mg QE/L \\
\hline \multicolumn{3}{|c|}{ Impatiens noli-tangere hydroalcoholic extract } \\
\hline MF extract & 590.2 & 184.8 \\
\hline UF concentrate extract & 983.7 & 449.5 \\
\hline \multicolumn{3}{|c|}{ Symphytum officinale hydroalcoholic extract } \\
\hline MF extract & 999.4 & 83.1 \\
\hline UF concentrate extract & 1303.1 & 114.1 \\
\hline
\end{tabular}

Table II

HPLC-MS polyphenolic profile of extracts

\begin{tabular}{lcc}
\hline \multicolumn{1}{c}{ Compound [M/z] } & $\begin{array}{c}\text { Concentration of polyphenolic compounds }(\mu \mathrm{g} / \mathrm{mL}) \\
\text { I. noli-tangere }\end{array}$ & S. officinale \\
\hline Ursolic acid [455.4] & $5.56 \pm 0.4$ & 4.05 \\
Chlorogenic acid [353] & $4.37 \pm 0.2$ & 0.25 \\
Caffeic acid [179] & - & 3.08 \\
Rosmarinic acid [359] & $49.86 \pm 2.8$ & 224.93 \\
Umbelliferone [161] & - & $2.95 \pm 0.1$ \\
Quercetin [301] & $10.33 \pm 0.8$ & $3.79 \pm 0.1$ \\
Luteolin [285] & $0.14 \pm 0.01$ & $0.17 \pm 0.01$ \\
Apigenin [269] & $0.09 \pm 0.01$ & - \\
Rutin [609] & $44.93 \pm 3.0$ & $4.91 \pm 0.1$ \\
Ellagic acid [301] & $1.58 \pm 0.1$ & $0.38 \pm 0.02$ \\
Quercetin 3- $\beta$-D-glucoside [463] & $56.70 \pm 4.2$ & $8.89 \pm 0.2$ \\
\hline
\end{tabular}

\section{Antimicrobial activity}

The susceptibility of the bacterial strains to the extract as well as that of the positive controls, can be found in Table III.

The 5 bacterial strains used for the microbiological testing are frequently isolated in burn wounds [19]. Our results indicate that the hydroalcoholic extract possess moderate antibacterial activity, in accordance to similar studies $[20,21]$. S. aureus, the bacteria which have been found to be one of the most common species able to readily infect burn wounds, seems to be the most sensitive microorganism, possibly as a result of specific phenolic compounds [20, 21]. 
Table III

Antimicrobial activities of the tested hydroalcoholic extract

\begin{tabular}{|c|c|c|c|c|c|}
\hline \multirow[b]{2}{*}{ Substance } & \multicolumn{5}{|c|}{ Inhibition area $(\mathrm{mm}) \pm \mathrm{SEM}$} \\
\hline & $\begin{array}{c}\text { S. aureus } \\
\text { ATCC } 25923\end{array}$ & $\begin{array}{l}\text { S. epidermidis } \\
\text { ATCC } 12228\end{array}$ & $\begin{array}{c}\text { B. cereus } \\
\text { ATCC } 11778\end{array}$ & $\begin{array}{c}\text { P. mirabilis } \\
\text { ATCC } 29245\end{array}$ & $\begin{array}{c}\text { E. coli } \\
\text { ATCC } 8739\end{array}$ \\
\hline Hydroalcoholic extract & $21 \pm 0.2$ & $17 \pm 0.4$ & $4 \pm 0.3$ & $7 \pm 0.3$ & $6 \pm 0.2$ \\
\hline Ethanol & ND & ND & ND & ND & ND \\
\hline Ampicilin $10 \mu \mathrm{g} / \mathrm{disc}$ & $31 \pm 0.7$ & $21 \pm 0.7$ & $11 \pm 0.5$ & $19 \pm 0.6$ & $9 \pm 0.3$ \\
\hline Ciprofloxacin $10 \mu \mathrm{g} /$ disc & $30 \pm 1.1$ & $29 \pm 0.8$ & $33 \pm 1.4$ & $38 \pm 1.2$ & $36 \pm 1.1$ \\
\hline Gentamicin $10 \mu \mathrm{g} /$ disc & $28 \pm 0.6$ & $18 \pm 0.2$ & $29 \pm 0.5$ & $29 \pm 0.8$ & $26 \pm 1$ \\
\hline
\end{tabular}

Values are the mean of 3 replicates. ND: Not determined

\section{Rate of wound contraction}

The wound evolution based on the values of the average surface/group of the thermal lesion areas before treatment (day 1) and following acute (1 administration) and subacute treatment (4 and 7 days of treatment) are presented in Figure 1.

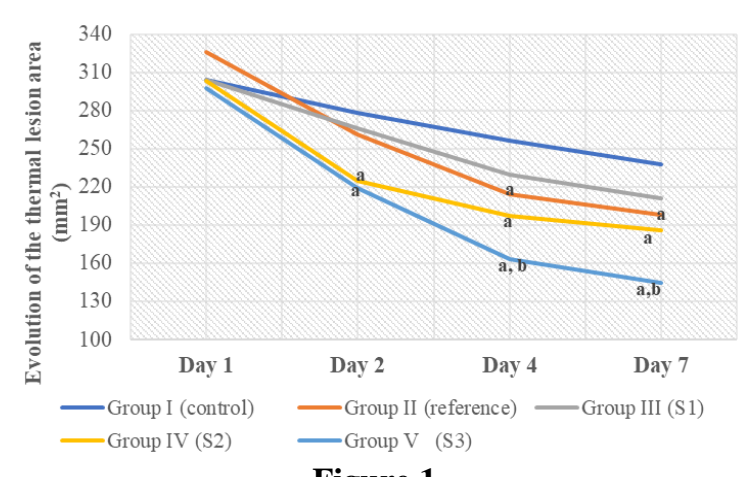

Figure 1.

Evolution of the thermal lesion area $\left(\mathrm{mm}^{2}\right)$ $\mathrm{a}-$ change $v s$. control ( $\mathrm{p}<0.05$, t Student, CI 95\%); b change $v s$. group II (reference) $(\mathrm{p}<0.05$, t Student, CI 95\%)

A better healing pattern characterized through a higher wound contraction rate was observed in all treated groups when compared to control. Support 3 showed greater healing properties when compared

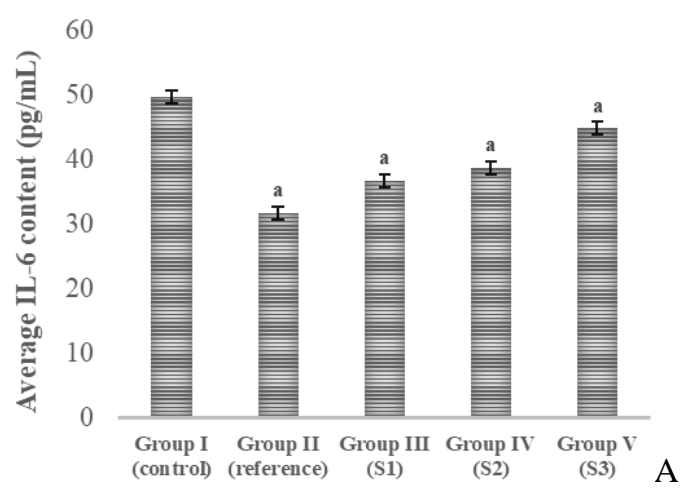

with silver sulphadiazine, the results suggesting a significant enhancement of the cicatrisation process. Biochemical analysis

The results of the assessment of the hydroxyproline content in granular tissue are given in Figure 2

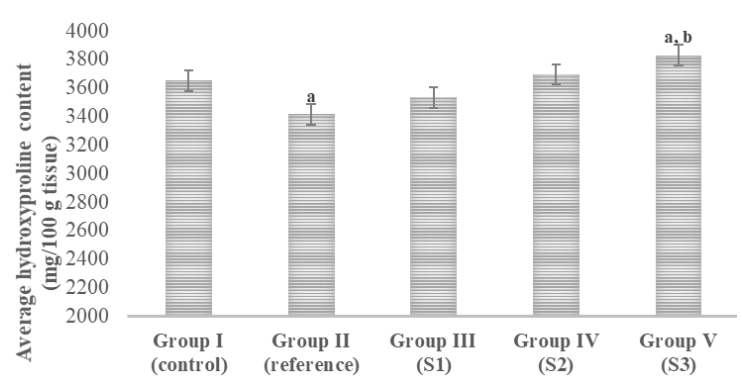

Figure 2.

Average content of hydroxyproline in granular tissue

$\mathrm{a}$ - change vs. control ( $\mathrm{p}<0.05$, t Student, CI 95\%); $\mathrm{b}-$ change $v s$. group II (reference) $(\mathrm{p}<0.05$, t Student, CI 95\%)

Collagen ensures the integrity and the strength of the extracellular matrix and is essential for healing [22]. Hydroxyproline, a major constituent of collagen, is used as an index of collagen turnover [3, 4, 23].

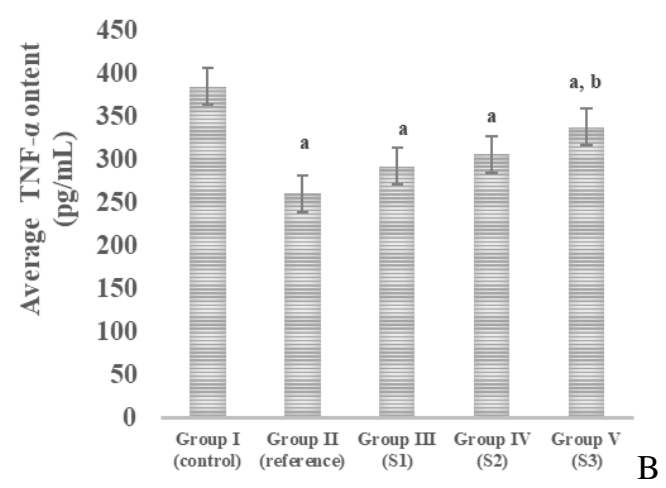

Figure 3.

Average blood concentration of proinflammatory cytokines A - mean blood concentration of IL-6. B - mean blood concentration of TNF- $\alpha$. $\mathrm{a}-$ Change $v s$. control, $\mathrm{p}<0.05, \mathrm{t}$ Student, CI 95\%; $\mathrm{b}$ - Change $v$ s. group II (reference), $\mathrm{p}<0.05$, t Student, CI $95 \%$

Support 3 significantly increases hydroxyproline content in the granular tissue, when compared to both control and silver sulphadiazine groups, indicating an increased collagen synthesis and thereby an increased 
cellular proliferation. Along with increasing collagen content, all treated groups present a lower serum level of IL-6 and TNF- $\alpha$ when compared with the control group (Figures 3A, 3B).

Silver sulphadiazine determines a significant decrease in the serum concentrations of IL- 6 and TNF- $\alpha v s$. control. These results are in accordance with those of several authors $[22,24]$. They also associate the alteration of the cytokines profile with a low healing effect of silver sulphadiazine [18-20]. The macrophages infiltrated at the site of injury secrete proinflammatory cytokines, such as IL-6 and TNF- $\alpha$ [22-26]. TNF- $\alpha$ determines the cascade release of secondary cytokines and humoral factors can induce the production of fibroblast growth factor-7 (FGF-7), suggesting that it can indirectly promote reepithelialisation [22, 25], while Il-6 has a mitogenic and proliferative [25] effect on keratinocytes [22]. Both cytokines seem to be necessary for the healing process, hypothesis which is in accordance with our data, support 3, the one that reduces non-significantly the cytokine profile when compared to control, demonstrating the greatest healing effect.

This decrease of cytokines level could be partly due to the presence of polyphenols and allantoin in the hydro-alcoholic extracts [26-30]. Furthermore, allantoin was shown to possess a complex healing effect, with topical application of allantoin leading to reduced chemotaxis of inflammatory cells into rat wounds and increased fibroblast proliferation and collagen synthesis [27-31], supporting thus the synthesis of extracellular matrix during wound healing.

In vitro assays demonstrated that caffeic acid and chlorogenic acid accelerated the proliferative response of fibroblasts, thus enhancing wound healing [29]. Polyphenolic compounds present in hydro-alcoholic extracts were shown to possess antioxidant and free radical scavenging properties, preventing the release of reactive species responsible for the oxidative stress and tissue damage in burns [10, 11].

\section{Conclusions}

Chitosan supports containing Impatiens noli-tangere and Symphytum officinale hydroalcoholic extracts possess a significant healing effect. The underlying mechanism is complex, including reduced chemotaxis of inflammatory cells into rat wounds and increased fibroblast proliferation and collagen synthesis.

Furthermore, the supports possess moderate antibacterial effect against $S$. aureus, one of the most common pathogens isolated in infected burn wounds, possibly due to specific phenolic compounds. These results suggest that the above-mentioned supports could be valuable tools for the treatment of burn wounds.

\section{Acknowledgement}

This study was supported by grant 202/2014 Biotechnological methods for obtaining new types of vectors for phytotherapeutic principles and modeling their delivery mechanisms (NEWBIOVECT).

\section{Conflict of interest}

The authors declare no conflict of interest.

\section{References}

1. Smolle C, Cambiaso-Daniel J, Forbes AA, Wurzer P, Hundeshagen G, Branski LK, Kamolz LP, Recent trends in burn epidemiology worldwide: A systematic review. Burns, 2017; 43(2): 249-257.

2. Klasen HJ, A historical review of the use of silver in the treatment of burns. II. Renewed interest for silver. Burns, 2000; 26(2): 131-138.

3. Priya KS, Gnanamani A, Radhakrishnan N, Babu M, Healing potential of Datura alba on burn wounds in albino rats. J Ethnopharmacol., 2002; 83(3):193199.

4. Akhoondinasab MR, Akhoondinasab M, Saberi M, Comparison of healing effect of Aloe vera extract and silver sulfadiazine in burn injuries in experimental rat model. World J Plast Surg., 2014; 3(1): 29-34.

5. Dorsett-Martin WA, Rat models of skin wound healing: a review. Wound Repair Regen., 2004; 12(6): 591599.

6. Li J, Chen J, Kirsner R, Pathophysiology of acute wound healing. Clin Dermatol., 2007; 25(1): 9-18.

7. Bielefeld KA, Amini-Nik S, Alman BA, Cutaneous wound healing: recruiting developmental pathways for regeneration. Cell Mol Life Sci., 2013; 70(12): 2059-2081.

8. Varga E, Fülöp I, Farczadi L, Ceoitoru MD, Polyphenolic determination from medicinal plants used in veterinary medicine by an UHPLC-LCMS/MS method. Farmacia, 2020; 68(6): 1129-1135.

9. Araujo LU, Reis PG, Barbosa LCO, Grabe-Guimarães A, Mosqueira VCF, Carneiro CM, Silva-Barcellos $\mathrm{NM}$, In vivo wound healing effects of Symphytum officinale L. leaves extract in different topical formulations. Pharmazie, 2012; 67(4): 355-360.

10. Papp N, Sali N, Csepregi R, Toth M, Gyergyák K, Dénes T, Bartha SG, Varga E, Kaszás A, Kőszegi $\mathrm{T}$, Antioxidant potential of some plants used in folk medicine in Romania. Farmacia, 2019; 67(2): 323330.

11. Paun G, Neagu E, Moroeanu V, Albu C, Ursu TM, Zanfirescu A, Radu GL, Anti-inflammatory and antioxidant activities of the Impatiens noli-tangere and Stachys officinalis polyphenolic-rich extracts. Revista Brasileira de Farmacognosia, 2018; 28(1): 57-64.

12. Szewczyk K, Zidorn C, Biernasiuk A, Komsta Ł, Granica S, Polyphenols from Impatiens (Balsaminaceae) and their antioxidant and antimicrobial activities. Ind Crop Prod., 2016; 86: 262-272.

13. Avram I, Lupaşcu FG, Confederat L, Constantin SM, Stan CI, Profire L, Chitosan microparticles loaded with antidiabetic drugs-preparation and characterization. Farmacia, 2017; 65(3): 443-448. 
14. Miguel SP, Moreira AF, Correia IJ, Chitosan basedasymmetric membranes for wound healing: A review. Int J Biol Macromolec., 2019; 127, 460-475.

15. Singleton VL, Orthofer R, Lamuela-Raventós RM, Analysis of total phenols and other oxidation substrates and antioxidants by means of Folin-Ciocalteu reagent. Methods in enzymology, 1999; 299: 152-178.

16. Lin JY, Tang CY, Determination of total phenolic and flavonoid contents in selected fruits and vegetables, as well as their stimulatory effects on mouse splenocyte proliferation. Food Chem., 2007; 101(1): 140-147.

17. Moraru AC, Roșca I, Crăciun B, Nicolescu A, Chiriac A, Voicu V, Insights of the antimicrobial activity of piperine extracted from Piper nigrum L. Farmacia, 2019; 67(6): 1099-1105.

18. Baoyong L, Jian Z, Denglong C, Min L, Evaluation of a new type of wound dressing made from recombinant spider silk protein using rat models. Burns, 2010; 36(6): 891-896.

19. Singh NP, Rani M, Gupta K, Sagar T, Kaur IR, Changing trends in antimicrobial susceptibility pattern of bacterial isolates in a burn unit. Burns, 2017; 43(5): 1083-1087.

20. Szewczyk K, Zidorn C, Biernasiuk A, Komsta Ł, Granica S. Polyphenols from Impatiens (Balsaminaceae) and their antioxidant and antimicrobial activities. Ind Crops Prod, 2016; 86: 262-272.

21. Woods-Panzaru S, Nelson D, McCollum G, Ballard LM, Millar BC, Maeda Y, Moore JE, An examination of antibacterial and antifungal properties of constituents described in traditional Ulster cures and remedies. Ulster Med J., 2009; 78(1): 13-15.

22. Lin ZQ, Kondo T, Ishida Y, Takayasu T, Mukaida N, Essential involvement of IL-6 in the skin woundhealing process as evidenced by delayed wound healing in IL-6-deficient mice. J leukocBiol., 2003; 73(6): 713-721.

23. Nayak BS, Pereira LMP, Catharanthus roseus flower extract has wound-healing activity in Sprague Dawley rats. BMC Comp Alt Med., 2006; 6(1): 41: 1-6.
24. Sato Y, Ohshima T, The expression of mRNA of proinflammatory cytokines during skin wound healing in mice: a preliminary study for forensic wound age estimation (II). Int J Legal Med., 2000; 113(3): 140-145.

25. Kubo H, Hayashi T, Ago K, Ago M, Kanekura T, Ogata M, Temporal expression of wound healingrelated genes in skin burn injury. Legal Med., 2014; 16(1): 8-13.

26. Gauglitz GG, Song J, Herndon DN, Finnerty CC, Boehning D, Barral JM, Jeschke MG, Characterization of the inflammatory response during acute and postacute phases after severe burn. Shock, 2008; 30(5): 503-507.

27. Barrientos S, Stojadinovic O, Golinko MS, Brem H, Tomic-Canic M, Growth factors and cytokines in wound healing. Wound Rep Regener., 2008; 16(5): 585-601.

28. Urdzikova LM, Ruzicka J, Karova K, Kloudova A, Svobodova B, Amin A, Jendelova P, A green tea polyphenol epigallocatechin-3-gallate enhances neuroregeneration after spinal cord injury by altering levels of inflammatory cytokines. Neuropharmacology, 2017; 126: 213-223.

29. Tsuruya M, Niwano Y, Nakamura K, Kanno T, Nakashima T, Egusa H, Sasaki K, Acceleration of proliferative response of mouse fibroblasts by shorttime pretreatment with polyphenols. Appl Biochem Biotechnol., 2014; 174(6): 2223-2235.

30. Paller A, Nardi R, Viereck JC, Barth J, An investigation into multifaceted mechanisms of action of allantoin in wound healing. J Am Acad Dermatol., 2017; 76(6): AB40-AB40.

31. Jorge MP, Madjarof C, Ruiz ALTG, Fernandes AT, Rodrigues RAF, de Oliveira Sousa IM, de Carvalho JE, Evaluation of wound healing properties of Arrabidaea chica Verlot extract. J Ethnopharmacol., 2008; 118(3): 361-366. 